\title{
Body composition and quality of life in adults treated with GH therapy: a systematic review and meta-analysis
}

\author{
Ahmad Hazem ${ }^{1,2}$, Mohamed B Elamin ${ }^{1}$, Irina Bancos ${ }^{3}$, German Malaga ${ }^{4,5}$, Gabriela Prutsky ${ }^{1,4,5}$, \\ Juan Pablo Domecq ${ }^{1,4,5}$, Tarig A Elraiyah ${ }^{1}$, Nisrin O Abu Elnour ${ }^{1}$, Yolanda Prevost ${ }^{4}$, Jaime P Almandoz ${ }^{1}$, \\ Claudia Zeballos-Palacios ${ }^{4}$, Edgar R Velasquez ${ }^{4}$, Patricia J Erwin ${ }^{1}$, Neena Natt ${ }^{3}$, Victor M Montori ${ }^{1,3}$ \\ and Mohammad Hassan Murad ${ }^{1,6}$ \\ ${ }^{1}$ Knowledge and Evaluation Research Unit, Mayo Clinic, 200 First Street SW, Rochester, Minnesota 55905, USA, ${ }^{2}$ Department of Internal Medicine, \\ University of North Dakota, Fargo, North Dakota, USA, ${ }^{3}$ Division of Endocrinology, Diabetes, Metabolism, Nutrition, Mayo Clinic, Rochester, Minnesota, \\ USA, ${ }^{4}$ Universidad Peruana Cayetano Heredia, Lima, Peru, ${ }^{5}$ Unidad de Conocimiento y Evidencia, Lima, Peru and ${ }^{6}$ Division of Preventive, Occupational and \\ Aerospace Medicine, Mayo Clinic, Rochester, Minnesota, USA,
}

(Correspondence should be addressed to M H Murad at Knowledge and Evaluation Research Unit, Mayo Clinic; Email: murad.mohammad@mayo.edu)

\begin{abstract}
Objective: To summarise the evidence about the efficacy and safety of using GH in adults with GH deficiency focusing on quality of life and body composition.

Data sources: We searched MEDLINE, EMBASE, Cochrane CENTRAL, Web of Science and Scopus through April 2011. We also reviewed reference lists and contacted experts to identify candidate studies. Study selection: Reviewers, working independently and in duplicate, selected randomised controlled trials (RCTs) that compared GH to placebo.

Data synthesis: We pooled the relative risk (RR) and weighted mean difference (WMD) by the random effects model and assessed heterogeneity using the $I^{2}$ statistic.

Results: Fifty-four RCTs were included enrolling over 3400 patients. The quality of the included trials was fair. $\mathrm{GH}$ use was associated with statistically significant reduction in weight (WMD, 95\% confidence interval $(95 \% \mathrm{CI}):-2.31 \mathrm{~kg},-2.66$ and -1.96$)$ and body fat content (WMD, 95\% CI: $-2.56 \mathrm{~kg}$, -2.97 and -2.16 ); increase in lean body mass (WMD, 95\% CI: 1.38, 1.10 and 1.65), the risk of oedema (RR, 95\% CI: 6.07, 4.34 and 8.48) and joint stiffness (RR, 95\% CI: 4.17, 1.4 and 12.38); without significant changes in body mass index, bone mineral density or other adverse effects. Quality of life measures improved in 11 of the 16 trials although meta-analysis was not feasible.

Results: GH therapy in adults with confirmed GH deficiency reduces weight and body fat, increases lean body mass and increases oedema and joint stiffness. Most trials demonstrated improvement in quality of life measures.
\end{abstract}

European Journal of Endocrinology 166 13-20

\section{Introduction}

GH and its effector insulin-like growth factor 1 (IGF1) serve mainly in regulating growth during childhood, while in adults it is thought to contribute to the regulation of weight, fat mass and muscle mass (1). Adult GH deficiency has been increasingly described as a syndrome, causing weight gain, decreased muscle mass and bone mineral density (BMD) and increased fat mass, impaired physical activity and poor quality of life and life expectancy.

Currently, the FDA-approved indications for GH replacement include short stature associated with Turner syndrome, renal failure, small size for gestational age, Prader-Willi syndrome, idiopathic short stature and for substitution in hypothalamic-pituitary disease (1). Availability of recombinant human GH provides a potential benefit to patients with GH deficiency but also carries disadvantages as there are safety and cost concerns related to long-term therapy. Previously published recommendations of GH use in adult GH deficiency were based on GH effects on physical function and quality of life $(1,2)$.

The evaluation of the efficacy of this intervention would not be complete without consideration of the potential adverse effects. Of those, the most commonly described are hyperglycaemia, hypertension, dyslipidaemia, oedema and joint complaints. Recently, concerns have been raised about the effect of $\mathrm{GH}$ use and the emergence or recurrence of cancer, and concerns about pituitary and craniopharyngioma tumour growth or recurrence (3).

In 1989, Jorgensen et al. (4) published the first randomised controlled trial (RCT) investigating the efficacy 
of using GH replacement therapy in deficient adults. The trial found that $\mathrm{GH}$ had several potential benefits in the patient population, including decrease in adipose volume, increase in muscle volume, increase in strength and exercise capacity of the quadriceps muscle and recovery of glomerular filtration rate and renal plasma flow. The trial concluded by encouraging future long-follow up trials to further investigate the effects of $\mathrm{GH}(5)$.

Since then, there have been several trials with varying durations of follow-up assessing the effects of GH on body composition, exercise capacity, strength and quality of life. Therefore, this systematic review aims to summarise the available randomised trial evidence in adults with GH deficiency treated with GH focusing on body composition (weight, body fat, lean body mass, BMD and body mass index (BMI)), functional outcomes and quality of life and adverse effects including oedema, joint stiffness and carpal tunnel syndrome. In this review, included trials were restricted - by a priori protocol - to trials that enrolled patients with confirmed diagnosis of GH deficiency. We excluded trials that used GH on patients with other conditions that are reportedly associated with GH deficiency including but not limited to obesity and the healthy elderly patients.

\section{Methods}

The report of this protocol-based review is consistent with the PRISMA statement (Preferred Reporting Items for Systematic Reviews and Meta-Analyses) (6).

\section{Eligibility criteria}

Eligible studies were randomised parallel placebocontrolled clinical trials of GH use in adult (age >18) patients with presumed GH deficiency (as defined in each study). Brief trials $(<3$ months) of GH use were excluded from our study.

\section{Study selection and data extraction}

An expert reference librarian (P J E) designed and conducted an electronic search strategy with input from study investigators with experience in systematic reviews (V M M and M H M). We searched electronic databases to identify relevant studies. These include: Ovid Medline, OVID EMBASE, OVID Cochrane Library, Web of Science, Scopus, PsycInfo and CINAHL through April 2011. We also sought input from content experts to suggest potentially eligible published and unpublished trials.

Two reviewers working independently and blindly considered the potential eligibility of each of the abstracts and titles that resulted from executing the search strategy; then evaluated the full text versions of all potentially eligible studies and extracted data from vetted references. Data extracted included description of study characteristics and participants' description, study quality indicators and outcomes. We used the GRADE approach to rate the quality of the evidence (7). Disagreements were resolved by consensus or if not possible, by arbitration.

\section{Statistical analysis}

The efficacy outcomes of interest were: i) health-related quality of life, ii) changes in body composition (anthropometric measurement or dual X-ray absorptiometry), iii) BMI and iv) skeletal mass. The safety outcomes were i) clinically significant hyperglycaemia, ii) hypertension, iii) dyslipidaemia, iv) clinically significant oedema, v) joint stiffness, vi) carpal tunnel syndrome, vii) cardiovascular events and viii) tumour occurrence or recurrence.

For dichotomous outcomes, we determined the relative risk (RR) and for continuous outcomes, we determined the weighted mean difference (WMD). Data were pooled by the DerSimonian and Laird random effects models (8). The $I^{2}$ statistic was used to measure inconsistency in results across studies. The $I^{2}$ statistic quantifies differences in results between studies that are not attributable to chance, therefore reflecting true inconsistency between different trials. An $I^{2}$ of more than $50 \%$ means that the inconsistency is large. Our analyses were performed by Comprehensive Meta-Analysis (CMA) version 2.2 (Biostat, Inc., Englewood, NJ, USA).

To seek explanations for inconsistency in results across trials, we planned several subgroup analyses. The a priori hypotheses included i) the proportion of participants lost to follow-up (over 10\% versus under $10 \%$ ), ii) the quality of allocation concealment and iii) the age of onset of the GH deficiency (childhood versus adulthood). For each of these analyses, we pooled results with random effects meta-analyses within each subgroup and then compared the results across pooled subgroups with a test of interaction (9). Furthermore, we performed post hoc meta-regression analysis for three continuous moderators: GH dose, baseline IGF1 and duration of GH treatment. We completed our analyses with assessment of publication bias using funnel plots that use the correlation of big sample size trials and positivity of their results as a basis to project an estimate of trials with negative results that are unpublished (10).

\section{Results}

\section{Search results}

From our primary search, we identified 2085 articles of which, 402 were selected for full text screening. Those were fully retrieved and screened for eligibility yielding 129 articles that met our inclusion criteria. Ultimately, following exclusion of articles with incomplete data and accounting for single trial duel and triple publications, there were 54 original parallel randomised placebocontrolled trials with sufficient data for analysis 
included in our review. Included trials enrolled over 3400 adult patients.

\section{Author contact}

We contacted authors of nine studies for clarification of published study details.

\section{Characteristic and quality of included trials}

Supplementary Table 1, (see section on supplementary data given at the end of this article) describes the characteristics of included studies. Included studies had a fair methodological quality with the majority (70\%) of included studies following up patients for 6 months (range: 3-24 months). Loss to follow-up was reported in $80 \%$ of included studies and averaged a mean (s.D.) of $7.44 \%$ (7.31). Eighty-nine percent of included studies reported the blinding of at least patients and caregivers while $7 \%$ were unblinded. Methods of randomisation and allocation concealment were reported in 11 and 5\% of included studies in that order. Furthermore, 23 and $44 \%$ of included studies reported implementing measures for assessment of adherence and efficacy of intervention. Source of funding was reported in 56\% of the studies and was found to have a for-profit component in $\sim 90 \%$ of those.

\section{GH efficacy}

Quality of life We found 16 trials that assessed quality of life outcomes in adult patients with GH deficiency. Pooling of the findings of those trials was not possible due to the heterogeneity in outcome reporting and the lack of quantitative data reported in trial reports (particularly, lack of reporting of measures of precision needed for meta-analysis).

All but five trials reported a statistically significant improvement in at least one subsection of used quality of life assessment tool, in patients who received active treatment. These findings are summarised in Supplementary Table 2, see section on supplementary data given at the end of this article.

Body composition GH use significantly and consistently reduced weight and body fat content while increasing lean body mass. WMD for weight was $-2.31 \mathrm{~kg}$ with a $95 \%$ confidence interval (CI) of -2.66 to -1.96 , and $I^{2}$ of $0 \%$. WMD $(95 \% \mathrm{CI})$ for body fat content was $-2.56 \mathrm{~kg}(-2.97$ and -1.3$)$ and $I^{2}$ of $73.7 \%$ (Fig. 1). WMD (95\% CI) for lean body mass was $1.38 \mathrm{~kg}$ (1.10 and 1.65). GH did not significantly affect BMI or BMD.

\begin{tabular}{|c|c|c|c|c|}
\hline \multirow[t]{2}{*}{ References } & \multicolumn{3}{|c|}{ Statistics for each study } & \\
\hline & $\begin{array}{l}\text { Difference } \\
\text { in means }\end{array}$ & $\begin{array}{l}\text { Lower } \\
\text { limit }\end{array}$ & $\begin{array}{l}\text { Upper } \\
\text { limit }\end{array}$ & $P$ value \\
\hline $\begin{array}{l}(44) \\
(45) \\
(46) \\
(47) \\
(48) \\
(49) \\
(50) \\
(51) \\
(52) \\
(53) \\
(54) \\
(55) \\
(56) \\
(57 ; \quad F \\
(57 ; \quad) \\
(58) \\
(59) \\
(60) \\
(61) \\
(62) \\
(63) \\
(64) \\
(65) \\
(66) \\
(67) \\
(68) \\
(69) \\
(70) \\
(71) \\
(72)\end{array}$ & $\begin{array}{r}-1.90 \\
-7.00 \\
-3.87 \\
-1.82 \\
-2.26 \\
-3.40 \\
-3.60 \\
-2.77 \\
-1.60 \\
-2.70 \\
-1.70 \\
-12.30 \\
-5.21 \\
-1.90 \\
-4.40 \\
-1.10 \\
-2.90 \\
-8.20 \\
-3.00 \\
-2.30 \\
-1.25 \\
-3.00 \\
-2.60 \\
-4.00 \\
-5.50 \\
-4.30 \\
0.40 \\
-6.00 \\
-2.08 \\
-1.00 \\
-2.56\end{array}$ & $\begin{array}{r}-8.18 \\
-11.21 \\
-10.58 \\
-2.95 \\
-2.36 \\
-9.47 \\
-5.69 \\
-3.64 \\
-2.62 \\
-6.44 \\
-7.64 \\
-23.54 \\
-10.46 \\
-7.31 \\
-8.22 \\
-5.65 \\
-3.74 \\
-19.48 \\
-3.14 \\
-4.29 \\
-4.21 \\
-9.50 \\
-3.51 \\
-10.95 \\
-16.41 \\
-8.10 \\
-1.41 \\
-8.78 \\
-8.97 \\
-8.52 \\
-2.97\end{array}$ & $\begin{array}{r}4.38 \\
-2.79 \\
2.84 \\
-0.69 \\
-2.16 \\
2.67 \\
-1.51 \\
-1.90 \\
-0.58 \\
1.04 \\
4.24 \\
-1.06 \\
0.04 \\
3.51 \\
-0.58 \\
3.45 \\
-2.06 \\
3.08 \\
-2.86 \\
-0.31 \\
1.71 \\
3.50 \\
-1.69 \\
2.95 \\
5.41 \\
-0.50 \\
2.21 \\
-3.22 \\
4.81 \\
6.52 \\
-2.16\end{array}$ & $\begin{array}{l}0.55 \\
0.00 \\
0.26 \\
0.00 \\
0.00 \\
0.27 \\
0.00 \\
0.00 \\
0.00 \\
0.16 \\
0.57 \\
0.03 \\
0.05 \\
0.49 \\
0.02 \\
0.64 \\
0.00 \\
0.15 \\
0.00 \\
0.02 \\
0.41 \\
0.37 \\
0.00 \\
0.26 \\
0.32 \\
0.03 \\
0.66 \\
0.00 \\
0.55 \\
0.79 \\
0.00\end{array}$ \\
\hline
\end{tabular}

$\begin{array}{ccc}\text { Sample size } \\ \text { GH } & \text { P } & \text { Total } \\ 23 & 13 & 36 \\ 20 & 23 & 43 \\ 11 & 12 & 23 \\ 30 & 31 & 61 \\ 59 & 57 & 116 \\ 7 & 6 & 13 \\ 10 & 9 & 19 \\ 60 & 55 & 115 \\ 15 & 16 & 31 \\ 8 & 8 & 16 \\ 7 & 8 & 15 \\ 10 & 10 & 20 \\ 14 & 15 & 29 \\ 26 & 33 & 59 \\ 34 & 30 & 64 \\ 9 & 7 & 16 \\ 34 & 34 & 68 \\ 5 & 5 & 10 \\ 85 & 80 & 165 \\ 14 & 15 & 29 \\ 13 & 14 & 27 \\ 9 & 9 & 18 \\ 19 & 16 & 35 \\ 13 & 11 & 24 \\ 11 & 12 & 23 \\ 11 & 14 & 25 \\ 16 & 14 & 30 \\ 14 & 11 & 25 \\ 17 & 13 & 30 \\ 11 & 11 & 22 \\ & & \end{array}$

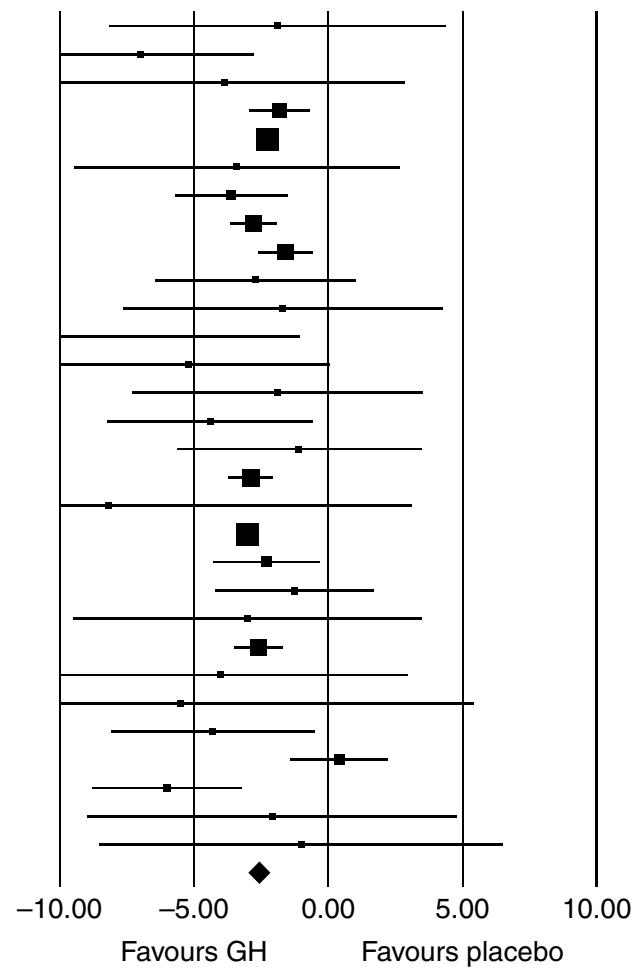

Figure 1 Meta-analysis of fat content change, measured in kg. $I^{2}=73.7 \%$. P, placebo; M, males; $\mathrm{F}$, females; $95 \% \mathrm{Cl}, 95 \%$ confidence interval. 
Adverse effects The data about adverse effects was in general of short-term relevance and the incidence of these events was too low, and very imprecise. GH use seems to reliably increase the risk of clinically significant oedema: RR 6.07 (95\% CI 4.34 and 8.84), $I^{2}=0 \%$ and joint stiffness: RR (95\% CI) 4.17 (1.40 and 12.38). We also found a trend that did not reach statistical significance for increasing the risk of carpal tunnel syndrome $(P=0.09)$.

There were no significant effects on risks of dyslipidaemia, hypertension, myocardial infarction, stroke, treatment requiring hyperglycaemia and tumour occurrence or recurrence.

Subgroup analyses, meta-regression and publication bias Subgroup analyses indicated that trials with a relatively high loss to follow-up rate $(>10 \%)$ reported significantly better lean body mass results $(P=0.02)$. Furthermore, we found a significant difference in the risk of carpal tunnel syndrome in trials that reported allocation concealment $(P=0.02)$. Sensitivity analysis was done with the exclusion of the one trial that did not report allocation concealment demonstrating a now-significant risk of carpal tunnel syndrome: RR (95\% CI) 5.83 (1.30 and 26.06).

Meta-regression demonstrated significant positive correlations between decrease in fat content and duration of follow-up $(P=0.01)$, baseline IGF 1 $(P<0.01)$ and $\mathrm{GH}$ dose $(P<0.01)$. We found a similar correlation between increase in lean body mass and baseline IGF1 $(P<0.01)$ and GH dose $(P=0.003)$.

Assessment for publication bias using funnel plots indicated significant publication biases for the outcomes of weight $(P=0.008)$, lean body mass $(P=0.0007)$, BMI $(0.045)$ and carpal tunnel syndrome $(P=0.04)$.

\section{Discussion}

\section{Summary of our findings}

This systematic review and meta-analysis demonstrated that $\mathrm{GH}$ replacement in adults with presumed $\mathrm{GH}$ deficiency is effective in decreasing patients' weight and body fat content while increasing their lean body mass. Changes to BMI and BMD were not statistically significant likely due to imprecision (small sample size). GH improves certain components of the quality of life indices; however, this inference is limited due to the heterogeneity in these indices. Safety data remains quite imprecise and inconclusive.

\section{Limitations and strengths of our review}

This study has several strengths including the comprehensive literature review, the appraisal of the risk of bias and the parsimonious set of planned analyses. However, several limitations exist. Most studies did not report the outcomes, we set out to summarise, increasing the risk of outcome reporting bias (11). Publication bias has affected several of the reported outcomes. Quality of life data was heterogeneous and meta-analysis was not feasible. Overall, the quality of evidence regarding the reduction in weight and body fat content is high; however, for all other outcomes remains low.

\section{Comparison with previous reviews}

The effects of $\mathrm{GH}$ replacement were assessed by a number of meta-analyses. Two recently published reviews described the efficacy of $\mathrm{GH}$ on physical activity and physiologic function. Widdowson \& Gibney (12) pooled the studies that measured the isometric and isokinetic quadriceps strength, while Rubeck et al. (13), looked at aerobic exercise capacity, $\mathrm{VO}_{2}$ max, maximal oxygen uptake, muscle strength and volume. This is in contrast to our review that focused primarily on the effects of $\mathrm{GH}$ on body composition, quality of life and safety.

The role of $\mathrm{GH}$ in improving quality of life was the focus of a systematic review conducted by Deijen et al. (14) in 2004. The review was not exclusive to randomised trials and included observational studies. As for the effects of GH on body composition, these were investigated by Maison et al. (15) in 2003. Our review brings the evidence base up to date and increases the precision of treatment estimates.

\section{Implications for practice and research}

While GH deficiency in adults has been reported to be associated with abnormalities in body composition, BMD, lipid and carbohydrate metabolism and quality of life, high quality evidence only supports the effects on the reductions in weight and body fat content. The clinical implication of these changes in body composition in GH deficient adults are unknown; as no studies to date have shown evidence that these changes are maintained on a long-term basis or that hard endpoints such as cardiovascular or cerebrovascular disease or mortality are improved. On the contrary, as of December 2010, the FDA is investigating the safety of recombinant human GH after a European observational study (Safety and Appropriateness of $\mathrm{GH}$ treatments in Europe: SAGhE) reported a 30\% increase in mortality risk with long-term use. The investigation is still underway, and the FDA recommends that any patient currently receiving rhGH to continue taking their medication (16).

Increase in fat mass is characteristic to GHD patients and is thought to be predominantly due to an increase in visceral compartment fat mass and a decrease in fat-free mass and total body water $(17,18)$. Various investigators demonstrated that fat mass was higher by around $7 \%$ in GHD patients compared with age, sex and height adjusted predicted values $(5,19,20)$. Reduction in fat mass after GH replacement therapy has been described mostly in the visceral fat mass using anthropometric 
measurements and imaging $(17,19,21)$. A recent study on the effect of GH replacement on different fat compartments by whole-body magnetic resonance imaging suggests GH replacement effect on both subcutaneous and visceral fat mass compartments (22).

GH implications in bone health and fracture reduction had been a matter of debate in endocrinology. Reduced BMD at various skeletal sites in GH deficiency subjects had been described. However, the results of $\mathrm{GH}$ replacement on bone mass had been conflicting. BMD gain had been noted to depend on variables as the level of BMD before commencement of GH therapy, replacement period of longer than 12-24 months, childhood versus adult onset GHD (23) and sex (24). Data on fracture incidence risk in untreated GHD is limited but seems to be increased $(25,26)$ and replacement with GH could decrease it especially in adult onset GHD men (27). In this review, GH was not found to be effective in increasing BMD.

Multiple studies demonstrate reduced quality of life in untreated patients with GH deficiency (28-30). Demonstration of a positive influence of GH replacement on the quality of life had been sought by several investigators with conflicting results (31-34). Recent observational data (35) showed long-term beneficial effects of GH replacement on quality of life as measured by adult GH deficiency assessment (AGHDA) score (36). In this review, this outcome was not commonly reported in published randomised trials included. Sixteen trials measured quality of life utilising various methods for quality of life assessment, most commonly including the aforementioned AGHDA score, along with the psychological general well-being index and the general health questionnaire. Frequently, the data was presented in a manner that rendered meta-analysis not possible, often omitting either pre- or post-intervention data and sometimes opting to verbally indicate whether there was any significant improvement. It is also worth noting that all available and utilised methods of quality of life assessment are self-reported and are susceptible to what is known as the response shift phenomenon $(37,38)$. With that in mind, we found that all but five of the 16 trials reported a statistically significant improvement in at least one subsection (e.g. energy, mental health and somatic health in the Nottingham Health Profile, the SF-36 and the symptom questionnaire) of the utilised quality of life assessment tool.

Interpretation of studies of the effectiveness of $\mathrm{GH}$ replacement in adults with GH deficiency is hampered by a number of confounding factors including identification of treatment goals. A major challenge to clinicians is how best to monitor and hence optimise GH replacement in their patients. At present, clinical guidelines on adult GH replacement recommend that treatment goals for each patient be individualised and guided by patient tolerability, appropriate clinical response and achievement of an IGF1 level in the age- and sex-appropriate reference range $(1,2,39)$.
However, to where exactly within the reference range an individual's IGF1 should be titrated remains unknown (40). In the general population, higher circulating IGF1 levels are associated with increased incidence of prostate, colorectal and premenopausal breast cancer (41). To date, however, there have been no published long-term studies in adults with GH deficiency treated with GH with respect to the development of non-pituitary malignancies. Another confounding factor when interpreting studies related to the efficacy of $\mathrm{GH}$ replacement in $\mathrm{GH}$ deficient adults is that most of these patients also have other pituitary hormone deficiencies that require replacement with glucocorticoid, thyroid hormone or sex steroids. The lack of biochemical tests to guide optimal replacement of these hormones, however, renders it possible that some symptoms and signs attributed to GH deficiency may in fact have been related to under- or over-replacement of other pituitary hormones. In addition, initiation of GH therapy in patients with hypopituitarism may alter dynamics of cortisol and thyroid hormone metabolism leading to unmasking of secondary hypothyroidism and hypoadrenalism that may subsequently go unrecognised by the physician $(42,43)$. To the extent that experts today understand and are able to use GH despite these uncertainties, important differences in outcomes between arms in randomised trials should arise, as we have seen with body composition outcomes, but not conclusively with other outcomes.

The development of recombinant $\mathrm{GH}$ replacement therapy in 1985 stimulated interest in the role of $\mathrm{GH}$ in adult life and the subsequent consequences of adult GH deficiency and its treatment. Despite the many studies published in this area, important questions still remain unanswered. Future research in the field should include conducting RCTs with long-term follow-up that enroll homogenous groups of $\mathrm{GH}$ deficient patients with similar causes and onset of disease and evaluate patient-important outcomes such as mortality and cardiovascular events, fractures and quality of life. These trials may compare varying doses of GH or include comparisons to other active interventions since comparison with placebo for a long time may be considered unethical. Funding of such trials may be challenging considering that $\mathrm{GH}$ already has an approved indication.

\section{Conclusion}

GH therapy in adults with GH deficiency reduces weight and body fat, increases lean body mass; but increases oedema and joint stiffness. Most trials demonstrated improvement in quality of life measures.

\section{Supplementary data}

This is linked to the online version of the paper at http://dx.doi.org/10. 1530/EJE-11-0558. 


\section{Declaration of interest}

The authors declare that there is no conflict of interest that could be perceived as prejudicing the impartiality of the research reported.

\section{Funding}

This review was commissioned and funded by a contract for the Endocrine Society (Grant \#: not applicable).

\section{References}

1 Molitch ME, Clemmons DR, Malozowski S, Merriam GR, Shalet SM, Vance ML \& Stephens PA. Evaluation and treatment of adult growth hormone deficiency: an Endocrine Society Clinical Practice Guideline. Journal of Clinical Endocrinology and Metabolism 200691 1621-1634. (doi:10.1210/jc.2005-2227)

2 Ho KK. Consensus guidelines for the diagnosis and treatment of adults with GH deficiency II: a statement of the GH Research Society in association with the European Society for Pediatric Endocrinology, Lawson Wilkins Society, European Society of Endocrinology, Japan Endocrine Society, and Endocrine Society of Australia. European Journal of Endocrinology 2007157 695-700. (doi:10.1530/EJE-07-0631)

3 Swerdlow AJ. Does growth hormone therapy increase the risk of cancer? Nature Clinical Practice. Endocrinology \& Metabolism 2006 2 530-531. (doi:10.1038/ncpendmet0295)

4 Jorgensen JO, Pedersen SA, Thuesen L, Jorgensen J, IngemannHansen T, Skakkebaek NE \& Christiansen JS. Beneficial effects of growth hormone treatment in GH-deficient adults. Lancet 1989 333 1221-1225. (doi:10.1016/S0140-6736(89)92328-3)

5 Snel YE, Doerga ME, Brummer RJ, Zelissen PM, Zonderland ML \& Koppeschaar HP. Resting metabolic rate, body composition and related hormonal parameters in growth hormone-deficient adults before and after growth hormone replacement therapy. European Journal of Endocrinology 1995133 445-450. (doi:10.1530/eje.0. 1330445)

6 Moher D, Liberati A, Tetzlaff J \& Altman DG. Preferred reporting items for systematic reviews and meta-analyses: the PRISMA statement. PLoS Medicine 20096 e1000097. (doi:10.1371/ journal.pmed.1000097)

7 Swiglo BA, Murad MH, Schunemann HJ, Kunz R, Vigersky RA, Guyatt GH \& Montori VM. A case for clarity, consistency, and helpfulness: state-of-the-art clinical practice guidelines in endocrinology using the grading of recommendations, assessment, development, and evaluation system. Journal of Clinical Endocrinology and Metabolism 200893 666-673. (doi:10.1210/jc. 2007-1907)

8 DerSimonian R \& Laird N. Meta-analysis in clinical trials. Controlled Clinical Trials 19867 177-188. (doi:10.1016/01972456(86)90046-2)

9 Altman DG \& Bland JM. Interaction revisited: the difference between two estimates. BMJ $2003 \mathbf{3 2 6}$ 219. (doi:10.1136/bmj. 326.7382.219)

10 Egger M, Davey Smith G, Schneider M \& Minder C. Bias in meta-analysis detected by a simple, graphical test. BMJ 1997315 629-634.

11 Furukawa TA, Watanabe N, Omori IM, Montori VM \& Guyatt GH. Association between unreported outcomes and effect size estimates in Cochrane meta-analyses. Journal of the American Medical Association 2007297 468-470. (doi:10.1001/jama.297. $5.468-b)$

12 Widdowson WM \& Gibney J. The effect of growth hormone (GH) replacement on muscle strength in patients with GH-deficiency: a meta-analysis. Clinical Endocrinology 201072 787-792. (doi:10.1111/j.1365-2265.2009.03716.x)

13 Rubeck KZ, Bertelsen S, Vestergaard P \& Jorgensen JO. Impact of $\mathrm{GH}$ substitution on exercise capacity and muscle strength in
GH-deficient adults: a meta-analysis of blinded, placebo-controlled trials. Clinical Endocrinology 200971 860-866. (doi:10.1111/ j.1365-2265.2009.03592.x)

14 Deijen JB, Arwert LI, Witlox J \& Drent ML. Differential effect sizes of growth hormone replacement on quality of life, well-being and health status in growth hormone deficient patients: a metaanalysis. Health and Quality of Life Outcomes 20053 63. (doi:10. 1186/1477-7525-3-63)

15 Maison P, Griffin S, Nicoue-Beglah M, Haddad N, Balkau B \& Chanson P. Impact of growth hormone $(\mathrm{GH})$ treatment on cardiovascular risk factors in $\mathrm{GH}$-deficient adults: a meta-analysis of blinded, randomized, placebo-controlled trials. Journal of Clinical Endocrinology and Metabolism 200489 2192-2199. (doi:10. 1210/jc.2003-030840)

16 FDA Drug Safety Podcast for Healthcare Professionals: ongoing safety review of Recombinant Human Growth Hormone (somatropin) and possible increased risk of death. 2010. http://www.fda. gov/Drugs/DrugSafety/DrugSafetyPodcasts/ucm238349.htm

17 Bengtsson BA, Eden S, Lonn L, Kvist H, Stokland A, Lindstedt G, Bosaeus I, Tolli J. Sjostrom L \& Isaksson OG. Treatment of adults with growth hormone $(\mathrm{GH})$ deficiency with recombinant human GH. Journal of Clinical Endocrinology and Metabolism 1993 76 309-317. (doi:10.1210/jc.76.2.309)

18 Carroll PV, Christ ER, Bengtsson BA, Carlsson L, Christiansen JS, Clemmons D, Hintz R, Ho K, Laron Z, Sizonenko P, Sonksen PH, Tanaka T \& Thorne M. Growth hormone deficiency in adulthood and the effects of growth hormone replacement: a review. Growth Hormone Research Society Scientific Committee. Journal of Clinical Endocrinology and Metabolism 199883 382-395. (doi:10.1210/ jc.83.2.382)

19 Salomon F, Cuneo RC, Hesp R \& Sonksen PH. The effects of treatment with recombinant human growth hormone on body composition and metabolism in adults with growth hormone deficiency. New England Journal of Medicine 1989321 1797-1803. (doi:10.1056/NEJM198912283212605)

20 Rosen T, Bosaeus I, Tolli J, Lindstedt G \& Bengtsson BA. Increased body fat mass and decreased extracellular fluid volume in adults with growth hormone deficiency. Clinical Endocrinology 199338 63-71. (doi:10.1111/j.1365-2265.1993.tb00974.x)

21 Snel YE, Doerga ME, Brummer RM, Zelissen PM \& Koppeschaar HP. Magnetic resonance imaging-assessed adipose tissue and serum lipid and insulin concentrations in growth hormone-deficient adults. Effect of growth hormone replacement. Arteriosclerosis, Thrombosis, and Vascular Biology 199515 1543-1548. (doi:10. 1161/01.ATV.15.10.1543)

22 Egger A, Buehler T, Boesch C, Diem P, Stettler C \& Christ ER. The effect of GH replacement therapy on different fat compartments: a whole-body magnetic resonance imaging study. European Journal of Endocrinology $2011 \mathbf{1 6 4}$ 23-29. (doi:10.1530/EJE-100702)

23 de Boer H, Blok GJ, van Lingen A, Teule GJ, Lips P \& van der Veen EA. Consequences of childhood-onset growth hormone deficiency for adult bone mass. Journal of Bone and Mineral Research 19949 1319-1326. (doi:10.1002/jbmr.5650090822)

24 Bex M \& Bouillon R. Growth hormone and bone health. Hormone Research 200360 (Suppl 3) 80-86. (doi:10.1159/000074507)

25 Rosen T, Wilhelmsen L, Landin-Wilhelmsen K, Lappas G \& Bengtsson BA. Increased fracture frequency in adult patients with hypopituitarism and GH deficiency. European Journal of Endocrinology 1997137 240-245. (doi:10.1530/eje.0.1370240)

26 Wuster C, Abs R, Bengtsson BA, Bennmarker H, FeldtRasmussen U, Hernberg-Stahl E, Monson JP, Westberg B \& Wilton P. The influence of growth hormone deficiency, growth hormone replacement therapy, and other aspects of hypopituitarism on fracture rate and bone mineral density. Journal of Bone and Mineral Research 200116 398-405. (doi:10.1359/jbmr.2001.16. 2.398)

27 Holmer H, Svensson J, Rylander L, Johannsson G, Rosen T, Bengtsson BA, Thoren M, Hoybye C, Degerblad M, Bramnert M, Hagg E, Engstrom BE, Ekman B, Thorngren KG, Hagmar L \& Erfurth EM. Fracture incidence in GH-deficient patients on 
complete hormone replacement including GH. Journal of Bone and Mineral Research 200722 1842-1850. (doi:10.1359/jbmr. 070811)

28 Rosen T, Wiren L, Wilhelmsen L, Wiklund I \& Bengtsson BA. Decreased psychological well-being in adult patients with growth hormone deficiency. Clinical Endocrinology 199440 111-116. (doi:10.1111/j.1365-2265.1994.tb02452.x)

29 Burman P, Broman JE, Hetta J, Wiklund I, Erfurth EM, Hagg E \& Karlsson FA. Quality of life in adults with growth hormone (GH) deficiency: response to treatment with recombinant human $\mathrm{GH}$ in a placebo-controlled 21-month trial. Journal of Clinical Endocrinology and Metabolism 199580 3585-3590. (doi:10. $1210 /$ jc. 80.12 .3585$)$

30 Wallymahmed ME, Baker GA, Humphris G, Dewey M \& MacFarlane IA. The development, reliability and validity of a disease specific quality of life model for adults with growth hormone deficiency. Clinical Endocrinology $1996 \mathbf{4 4} 403-411$. (doi:10.1046/j.1365-2265.1996.704523.x)

31 McGauley GA, Cuneo RC, Salomon F \& Sonksen PH. Psychological well-being before and after growth hormone treatment in adults with growth hormone deficiency. Hormone Research 199033 (Suppl 4) 52-54. (doi:10.1159/000181584)

32 Svensson J, Mattsson A, Rosen T, Wiren L, Johannsson G, Bengtsson BA \& Koltowska Haggstrom M. Three-years of growth hormone $(\mathrm{GH})$ replacement therapy in GH-deficient adults: effects on quality of life, patient-reported outcomes and healthcare consumption. Growth Hormone \& IGF Research 2004 14 207-215. (doi:10.1016/j.ghir.2003.12.001)

33 Baum HB, Katznelson L, Sherman JC, Biller BM, Hayden DL, Schoenfeld DA, Cannistraro KE \& Klibanski A. Effects of physiological growth hormone (GH) therapy on cognition and quality of life in patients with adult-onset GH deficiency. Journal of Clinical Endocrinology and Metabolism $1998 \quad 83$ 3184-3189. (doi:10.1210/jc.83.9.3184)

34 Murray RD, Skillicorn CJ, Howell SJ, Lissett CA, Rahim A \& Shalet SM. Dose titration and patient selection increases the efficacy of GH replacement in severely GH deficient adults. Clinical Endocrinology 199950 749-757. (doi:10.1046/j.1365-2265. 1999.00722.x)

35 Spielhagen C, Schwahn C, Moller K, Friedrich N, Kohlmann T, Moock J, Koltowska-Haggstrom M, Nauck M, Buchfelder M \& Wallaschofski $\mathrm{H}$. The benefit of long-term growth hormone (GH) replacement therapy in hypopituitary adults with GH deficiency: results of the German KIMS database. Growth Hormone $\mathcal{E}$ IGF Research 201021 1-10. (doi:10.1016/j.ghir.2010.10.005)

36 McKenna SP, Doward LC, Alonso J, Kohlmann T, Niero M, Prieto L \& Wiren L. The QoL-AGHDA: an instrument for the assessment of quality of life in adults with growth hormone deficiency. Quality of Life Research 19998 373-383. (doi:10.1023/A: 1008987922774)

37 Ring L, Hofer S, Heuston F, Harris D \& O'Boyle CA. Response shift masks the treatment impact on patient reported outcomes (PROs): the example of individual quality of life in edentulous patients. Health and Quality of Life Outcomes 20053 55. (doi:10.1186/ 1477-7525-3-55)

38 Sprangers MA \& Schwartz CE. Integrating response shift into health-related quality of life research: a theoretical model. Social Science \& Medicine 199948 1507-1515. (doi:10.1016/S02779536(99)00045-3)

39 Cook DM, Yuen KC, Biller BM, Kemp SF \& Vance ML. American Association of Clinical Endocrinologists medical guidelines for clinical practice for growth hormone use in growth hormonedeficient adults and transition patients - 2009 update. Endocrine Practice 200915 (Suppl 2) 1-29.

40 Higham CE, Jostel A \& Trainer PJ. IGF-I measurements in the monitoring of GH therapy. Pituitary 200710 159-163. (doi:10. 1007/s11102-007-0027-9)

41 Renehan AG, Zwahlen M, Minder C, O'Dwyer ST, Shalet SM \& Egger M. Insulin-like growth factor (IGF)-I, IGF binding protein-3, and cancer risk: systematic review and meta-regression analysis. Lancet 2004363 1346-1353. (doi:10.1016/S0140-6736(04) 16044-3)

42 Porretti S, Giavoli C, Ronchi C, Lombardi G, Zaccaria M, Valle D, Arosio M \& Beck-Peccoz P. Recombinant human GH replacement therapy and thyroid function in a large group of adult GH-deficient patients: when does L-T(4) therapy become mandatory? Journal of Clinical Endocrinology and Metabolism 200287 2042-2045. (doi:10.1210/jc.87.5.2042)

43 Giavoli C, Libe R, Corbetta S, Ferrante E, Lania A, Arosio M, Spada A \& Beck-Peccoz P. Effect of recombinant human growth hormone $(\mathrm{GH})$ replacement on the hypothalamic-pituitaryadrenal axis in adult GH-deficient patients. Journal of Clinical Endocrinology and Metabolism 200489 5397-5401. (doi:10. 1210/jc.2004-1114)

44 Albert SG \& Mooradian AD. Low-dose recombinant human growth hormone as adjuvant therapy to lifestyle modifications in the management of obesity. Journal of Clinical Endocrinology and Metabolism 200489 695-701. (doi:10.1210/jc.2003-031264)

45 Beauregard C, Utz AL, Schaub AE, Nachtigall L, Biller BM, Miller KK \& Klibanski A. Growth hormone decreases visceral fat and improves cardiovascular risk markers in women with hypopituitarism: a randomized, placebo-controlled study. Journal of Clinical Endocrinology and Metabolism 200893 2063-2071. (doi:10.1210/jc.2007-2371)

46 Bell W, Davies JS, Evans WD \& Scanlon MF. Effect of recombinant human growth hormone on regional tissue distribution in growth hormone-deficient males. Annals of the New York Academy of Sciences 2000904 576-583. (doi:10.1111/j.1749-6632.2000. tb06519.x)

47 Chihara K, Kato Y, Takano K, Shimatsu A, Kohno H, Tanaka T \& Irie M. Effect of growth hormone treatment on trunk fat accumulation in adult GH-deficient Japanese patients: a randomised, placebo-controlled trial. Current Medical Research and Opinion 200622 1973-1979. (doi:10.1185/030079906X132460)

48 Chihara K, Kato Y, Shimatsu A, Tanaka T \& Kohno H. Efficacy and safety of individualized growth hormone treatment in adult Japanese patients with growth hormone deficiency. Growth Hormone and IGF Research 200818 394-403. (doi:10.1016/j. ghir.2008.02.002)

49 Christ ER, Cummings MH, Jackson N, Stolinski M, Lumb PJ, Wierzbicki AS, Sonksen PH, Russell-Jones DL \& Umpleby AM. Effects of growth hormone $(\mathrm{GH})$ replacement therapy on lowdensity lipoprotein apolipoprotein B100 kinetics in adult patients with GH deficiency: a stable isotope study. Journal of Clinical Endocrinology and Metabolism 200489 1801-1807. (doi:10. 1210/jc.2003-031474)

50 Chung YS, Lee HC, Hwang SK, Paik IK, Lee JH \& Huh KB. Growth hormone replacement therapy in adults with growth hormone deficiency; thrice weekly low dose administration. Journal of Korean Medical Science 19949 169-178.

51 Ezzat S, Fear S, Gaillard RC, Gayle C, Landy H, Marcovitz S, Mattioni T, Nussey S, Rees A \& Svanberg E. Gender-specific responses of lean body composition and non-gender-specific cardiac function improvement after $\mathrm{GH}$ replacement in GH-deficient adults. Erratum appears in Journal of Clinical Endocrinology and Metabolism 200210 4461. Journal of Clinical Endocrinology and Metabolism 200287 2725-2733. (doi:10. $1210 /$ jc.87.6.2725)

52 Fernholm R, Bramnert M, Hagg E, Hilding A, Baylink DJ, Mohan S \& Thoren M. Growth hormone replacement therapy improves body composition and increases bone metabolism in elderly patients with pituitary disease. Journal of Clinical Endocrinology and Metabolism 200085 4104-4112. (doi:10.1210/jc.85.11. 4104)

53 Gibney J, Healy ML, Stolinski M, Bowes SB, Pentecost C, Breen L, McMillan C, Russell-Jones DL, Sonksen PH \& Umpleby AM. Effect of growth hormone (GH) on glycerol and free fatty acid metabolism during exhaustive exercise in $\mathrm{GH}$-deficient adults. Journal of Clinical Endocrinology and Metabolism $2003 \mathbf{8 8}$ 1792-1797. (doi:10.1210/jc.2002-020540) 
54 Gilsanz Peral A, Halperin I, Vilardell E \& Ulied A. Effects of treatment with rhGH in adults with GH deficiency. Endocrinologia 199441 35-39.

55 Gomez JM, Gomez N, Fiter J \& Soler J. Effects of long-term treatment with $\mathrm{GH}$ in the bone mineral density of adults with hypopituitarism and GH deficiency and after discontinuation of GH replacement. Hormone and Metabolic Research 200032 66-70. (doi:10.1055/s-2007-978591)

56 Hansen TB, Vahl N, Jorgensen JO, Christiansen JS \& Hagen C. Whole body and regional soft tissue changes in growth hormone deficient adults after one year of growth hormone treatment: a double-blind, randomized, placebo-controlled study. Clinical Endocrinology 199543 689-696. (doi:10.1111/j.1365-2265. 1995.tb00536.x)

57 Hoffman AR, Kuntze JE, Baptista J, Baum HB, Baumann GP, Biller BM, Clark RV, Cook D, Inzucchi SE, Kleinberg D, Klibanski A, Phillips LS, Ridgway EC, Robbins RJ, Schlechte J, Sharma M, Thorner MO \& Vance ML. Growth hormone $(\mathrm{GH})$ replacement therapy in adult-onset gh deficiency: effects on body composition in men and women in a double-blind, randomized, placebocontrolled trial. Journal of Clinical Endocrinology and Metabolism 200489 2048-2056. (doi:10.1210/jc.2003-030346)

58 Hwu CM, Kwok CF, Lai TY, Shih KC, Lee TS, Hsiao LC, Lee SH, Fang VS \& Ho LT. Growth hormone $(\mathrm{GH})$ replacement reduces total body fat and normalizes insulin sensitivity in GH-deficient adults: a report of one-year clinical experience. Journal of Clinical Endocrinology and Metabolism 199782 3285-3292. (doi:10. $1210 /$ jc.82.10.3285)

59 Johannsson G, Bjarnason R, Bramnert M, Carlsson LMS, Degerblad M, Manhem P, Rosen T, Thoren M \& Bengtsson BA. The individual responsiveness to growth hormone $(\mathrm{GH})$ treatment in GH-deficient adults is dependent on the level of GH-binding protein, body mass index, age, and gender. Journal of Clinical Endocrinology and Metabolism 199581 1575-1581. (doi:10. $1210 /$ jc. 81.4.1575)

60 Luisetto G, Zaccaria M, Cestaro S, Camozzi V, Angelini F \& Moise M. Effect of growth hormone replacement therapy on bone mass, bone metabolism, and body composition in adult patients with growth hormone deficiency. Current Therapeutic Research Clinical and Experimental 199960 237-249. (doi:10.1016/ S0011-393X(00)88519-7)

61 Mesa J, Gomez JM, Hernandez C, Pico A, Ulied A \& Grupo Colaborador E. Growth hormone deficiency in adults: effects of replacement therapy on body composition and health-related quality of life. Medicina Clinica 2002120 41-46. (doi:10.1157/ 13042257)

62 Miller KK, Wexler T, Fazeli P, Gunnell L, Graham GJ, Beauregard C, Hemphill L, Nachtigall L, Loeffler J, Swearingen B, Biller BM \& Klibanski A. Growth hormone deficiency after treatment of acromegaly: a randomized, placebo-controlled study of growth hormone replacement. Journal of Clinical Endocrinology and Metabolism 201095 567-577. (doi:10.1210/jc.2009-1611)

63 Newman CB, Frisch KA, Rosenzweig B, Roubenoff R, Rey M, Kidder T, Kong Y, Pursnani A, Sedlis SP, Schwartzbard A \& Kleinberg DL. Moderate doses of hGH (0.64 mg/d) improve lipids but not cardiovascular function in GH-deficient adults with normal baseline cardiac function. Journal of Clinical Endocrinology and Metabolism 201196 122-132. (doi:10.1210/jc.2010-1204)

64 Norrelund H, Vahl N, Juul A, Moller N, Alberti KG, Skakkebaek NE, Christiansen JS \& Jorgensen JO. Continuation of growth hormone (GH) therapy in GH-deficient patients during transition from childhood to adulthood: impact on insulin sensitivity and substrate metabolism. Journal of Clinical Endocrinology and Metabolism 200085 1912-1917. (doi:10.1210/jc.85.5.1912)

65 Rodriguez-Arnao J, Jabbar A, Fulcher K, Besser GM \& Ross RJ. Effects of growth hormone replacement on physical performance and body composition in GH deficient adults. Clinical Endocrinology 199951 53-60. (doi:10.1046/j.1365-2265.1999.00737.x)

66 Rosenfalck AM, Fisker S, Hilsted J, Dinesen B, Volund A, Jorgensen JO, Christiansen JS \& Madsbad S. The effect of the deterioration of insulin sensitivity on beta-cell function in growthhormone-deficient adults following 4-month growth hormone replacement therapy. Growth Hormone and IGF Research 19999 96-105. (doi:10.1054/ghir.1999.0091)

67 Salomon F, Cuneo RC, Hesp R \& Sonksen PH. The effects of treatment with recombinant human growth hormone on body composition and metabolism in adults with growth hormone deficiency. New England Journal of Medicine 1989321 1797-1803. (doi:10.1056/NEJM198912283212605)

68 Snel YE, Brummer RJ, Doerga ME, Zelissen PM \& Koppeschaar HP. Energy and macronutrient intake in growth hormone-deficient adults: the effect of growth hormone replacement. European Journal of Clinical Nutrition $1995 \mathbf{4 9} 492-500$.

69 Stiegler C \& Leb G. One year of replacement therapy in adults with growth hormone deficiency. Endocrinology and Metabolism $1994137-42$.

70 Underwood LE, Attie KM \& Baptista J. Growth hormone (GH) doseresponse in young adults with childhood-onset GH deficiency: a two-year, multicenter, multiple-dose, placebo-controlled study. Journal of Clinical Endocrinology and Metabolism $2003 \mathbf{8 8}$ 5273-5280. (doi:10.1210/jc.2003-030204)

71 Wallymahmed ME, Foy P, Shaw D, Hutcheon R, Edwards RH \& MacFarlane IA. Quality of life, body composition and muscle strength in adult growth hormone deficiency: the influence of growth hormone replacement therapy for up to 3 years. Clinical Endocrinology 199747 439-446. (doi:10.1046/j.1365-2265. 1997.2801076.x)

72 Weaver JU, Monson JP, Noonan K, Price C, Edwards A, Evans KA, James I \& Cunningham J. The effect of low dose recombinant human growth hormone replacement on indices of bone remodelling and bone mineral density in hypopituitary growth hormone-deficient adults. Endocrinology and Metabolism 19943 $55-61$.

Received 8 May 2011

Revised version received 21 August 2011

Accepted 24 August 2011 